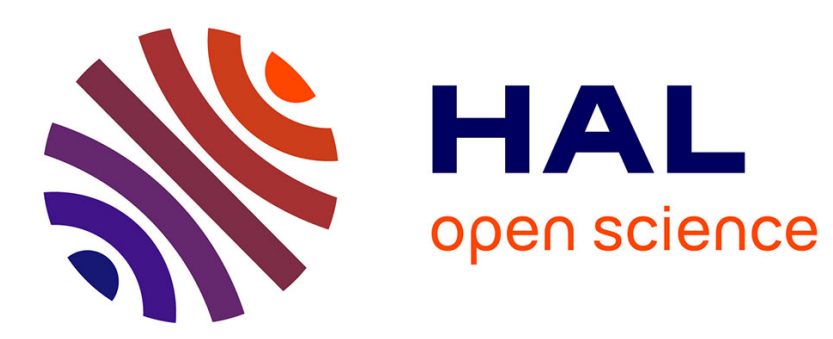

\title{
Bilingual Speech and Language Ecology in Greek Thrace: Romani and Pomak in contact with Turkish
}

Evangelia Adamou

\section{To cite this version:}

Evangelia Adamou. Bilingual Speech and Language Ecology in Greek Thrace: Romani and Pomak in contact with Turkish. Language in Society, 2010, 39 (2), pp.147-171. 10.1017/S0047404510000035 . hal-00410676v2

\author{
HAL Id: hal-00410676 \\ https://hal.science/hal-00410676v2
}

Submitted on 24 Sep 2009

HAL is a multi-disciplinary open access archive for the deposit and dissemination of scientific research documents, whether they are published or not. The documents may come from teaching and research institutions in France or abroad, or from public or private research centers.
L'archive ouverte pluridisciplinaire HAL, est destinée au dépôt et à la diffusion de documents scientifiques de niveau recherche, publiés ou non, émanant des établissements d'enseignement et de recherche français ou étrangers, des laboratoires publics ou privés. 


\title{
Bilingual Speech and Language Ecology in Greek Thrace: \\ Romani and Pomak in contact with Turkish
}

\author{
Evangelia ADAMOU \\ Oral Tradition Languages and Civilizations (LACITO), \\ French National Center for Scientific Research (CNRS) \\ 7, rue Guy Moquet \\ 94801 Villejuif, France \\ adamou@vjf.cnrs.fr
}

In Memory of Pr. Lukas D. Tsitsipis

\begin{abstract}
This paper examines the influence of language ecology (Mufwene 2001, 2005) on bilingual speech. It is based on first hand data from two undocumented varieties of Romani and Pomak in contact with Turkish in Greek Thrace, in both cases Turkish being an important language for the community's identity. This analysis shows, on one hand, how the RomaniTurkish fused lect (Auer 1998) was produced by intensive and extensive bilingualism through colloquial contact with the trade language, Turkish. On the other hand, it shows how semisedentary Pomak speakers had limited, institutional contact with Turkish, resulting in more traditional codeswitching and emblematic lexical borrowings.
\end{abstract}

KEY-WORDS: Language contact, bilingual speech, fused lect, language ecology, Pomak, Romani, Turkish, Greece 
This paper ${ }^{\mathrm{i}}$ addresses the question of how language ecology shapes the bilingual speech observed in multilingual settings. It is based on present-day, first hand data from two previously undocumented varieties of Romani and Pomak in contact with Turkish in Greek Thrace. In order to isolate the relevant parameters, I chose to compare these two communities within the Muslim Minority of Thrace, which are very different in terms of their socioprofessional and cultural profiles but live in roughly the same area and share long term contact with Turkish. This contact began in Ottoman times and continued in both communities throughout the $20^{\text {th }}$ century. From the perspective of language contact outcomes, despite some similarities in the borrowings, close study reveals that Turkish has a radically different status in these two languages: Komotini Romani is an example of what Auer (1998) names fused lect, i.e. stabilized codeswitching, with a high number of borrowings (verbs, nouns, adverbs, conjunctions) and a variety of borrowing strategies (such as complete verb paradigm transfer, borrowed inflexion for masculine nouns, etc.). Pomak, on the other hand, shows fewer borrowings, with only a few verbs, and more habitual discourse and participant related codeswitching. As I argue in this paper, the above differences are related to the patterns of language contact in these societies, which in turn are related to the speech community ecology.

\section{AN OVERVIEW OF LANGUAGE CONTACT AND SOCIAL FACTORS IN THE EXISTING LITERATURE}

The term ecology of language, as applied to linguistics by Mufwene (2001 following Voegelin, Voegelin \& Schultz 1967 and Haugen 1972) refers to the analysis of language as a complex, adaptive system to the external, social environment and the internal, language variation. Studying the ecology of a language implies a close look at the social, ethnographic, cultural and economic environment in which the language is spoken, including a wide range of factors such as population size, changes in living conditions, etc. Moreover, from a macroecological perspective, Mufwene suggests that the study of language ecology should also include system-internal, linguistic factors, such as language contact, cross-dialectal and inter-idiolectal variation as well as structural linguistic features (Mufwene 2001: 22). Thus the term 'language ecology' has come to cover all the parameters, external and internal, necessary for understanding language contact.

In the tradition of Weinreich (1953), relations between language contact outcomes and the type of society they are produced in, have frequently been the center of attention. An 
Bilingual Speech and Language Ecology in Greek Thrace:

Romani and Pomak in Contact with Turkish

attempt to correlate the intensity of contact and the language contact outcomes led to the proposal of a borrowing scale (Thomason \& Kaufman 1988: 74-75) ranging from "casual contact" and lexical borrowing, to "very strong cultural pressure" and heavy structural borrowing. Winford (2003), following Loveday (1996), also correlates the degree of bilingualism and contact phenomena through a continuum which starts with "distant" contact and lexical borrowing and ends with high multilingualism in heterogeneous communities. Trudgill (see 1989, or more recently Trudgill 2008 vs. Mufwene 2008) has also convincingly shown how social and sociolinguistic parameters shape contact induced change. More specifically, he has studied community size (large vs. small), social network structures (tight vs. loose) and types of contact (low vs. high, long-term contact with child bilingualism vs. short-term contact with adult bilingualism). Recent studies in contact linguistics pursue this approach, taking into consideration the external factors which facilitate the diffusion of linguistic features (Aikhenvald \& Dixon 2007). From a synchronic viewpoint, the study of codeswitching phenomena has contributed to a better understanding of language contact mechanisms. The constraints and social significance of bilingual speech are analyzed in a more advantageous manor, and it is possible to combine macro- and micro-level analyses: see among others Poplack 1980, Gumperz 1982, Myers-Scotton 1993a and 1993b, and SilvaCorvalàn 1994.

However, Matras (2007) challenges the importance traditionally assigned to social parameters by claiming that the sources of borrowing are to be found in "the need to reduce the cognitive load" (Matras 2007: 67; following Matras 1998). Contrary to Thomason and Kaufman who claim that "it is the sociolinguistic history of the speakers [...] that is the primary determinant of the linguistic outcome of language contact. Purely linguistic considerations are relevant but strictly secondary overall" (1988: 35), for Matras sociolinguistic factors are relevant, yet, secondary; they do not trigger but rather "license" the speakers to "dismantle the mental demarcation boundaries that separate their individual languages" (Matras 2007: 68).

The present case study brings some new insight to this debate. On the one hand, Pomak and Romani share some borrowings from Turkish that agree with the universal borrowability hierarchy proposed by Matras (2007): for example they have both borrowed the adversative marker, numerals and the same time expressions and indefinite nouns. On the other hand, the degree and type of contact, factors directly dependant on the social environment, explain to a great extent the differences observed in the products of language contact in the two cases. 


\section{AN INTRODUCTION TO POMAK AND ROMANI}

Both Balkan and Romani studies have long been at the heart of contact linguistics. The Balkan "Sprachbund" was proposed by Troubetzkoy in 1928 based on earlier works by Kopitar 1829, Schleicher 1850, Miklosič 1861 and Sandfeld 1926. In modern studies, it accounts for the fact that many unrelated Balkan languages have "converged", meaning they have developed parallel syntactic structures that do not occur in the genetically related languages to be found outside the Sprachbund. At the top of the hierarchy stand the South Slavic languages, Macedonian and to a lesser degree Bulgarian and Serbian, as well as the Aromanian dialects, Albanian and to some extent Greek. Although Romani has also participated in the areal convergence phenomena and is considered as a 'balkanized' IndoAryan language, Romani dialects are most well known for their "language mixing".

\subsection{Pomak}

Pomatsko 'Pomak' is the name used for the South Slavic variety spoken by Muslim inhabitants of the Rhodope Mountains in Greece, who often migrated to other cities or countries during the second half of the $20^{\text {th }}$ century - cf. Figure 1 . The origins of the Pomaks are very controversial and largely dependant on State ideologies; Turkish researchers claim that Pomaks are of Turkic origin and shifted to Slavic, Bulgarian researchers that Pomaks are Slavs who were converted to Islam, and some Greek researchers relate them to pre-Slavic and pre-Turkic local populations. This study focuses on a Pomak variety spoken in a village of the Xanthi area which I will refer to as Pomak $1 .{ }^{\text {ii }}$ I carried out fieldwork in this village on four occasions between 2005 and 2009, combining work with questionnaires with, more significantly, observation of natural speech production in natural contexts.

The Pomaks living in Thrace, together with the Turks and Muslim Roma, were exempted from the obligatory exchange of populations that took place in the 1920s when the Ottoman rule collapsed. They were guaranteed the right to bilingual education in Greek (the State language) and Turkish (the Muslim minority language) (1923, Lausanne Treaty). In this context, a shift to Turkish became generalized in the second half of the $20^{\text {th }}$ century, ${ }^{\text {iii }}$ as it was considered by the communities as a more useful language for social advancement, also motivated by the community's strong religious identity (Greek is the emblematic language to which the Christian populations in Modern Greece shifted).

Contrary to the general tendency to shift to Turkish, in the village under study (and more broadly in the general area) Pomak is still transmitted to children and is used in 
everyday communication. The majority of the speakers in this village are trilingual. The younger generation, men and women, have learnt Greek and Turkish at school, within the "Minoritariste" primary school educational system. However, monolingual speakers are still to be found among the eldest women. Most frequently, women over 50 have basic communicational skills in Greek and Turkish, limited to greetings and short conversation (Adamou \& Drettas 2008).

Pomak1 shares some common Balkan Sprachbund properties, such as a 'will' future, a subjunctive, the dative/genitive merger and postposed articles. Compared to the closest related South Slavic languages, Pomak1 shows some interesting features: for example it has preserved, to a certain extent, its case system - distinguishing between the Nominative, the Dative-Genitive and the Accusative, the latter being subjected to differential marking related to humanness (see Adamou in press a). Note that loss of the case system is one of the main features that serve to distinguish Bulgarian and Macedonian from Serbian; Bulgarian and Macedonian have developed an analytical system (based on prepositions) for the same functions.

Moreover, Pomak1 shows some features which are exceptional for Slavic languages in general, e.g. the overt expression of deixis in the formation of temporal conjunctions, indicating the anchoring of the event in the speech time situation (see Adamou in press b). The deictic suffixes also constitute the definite articles and the demonstratives: for 'here and now' situations, the entities considered as being part of the 'speaker's sphere' receive the $-s$ suffix, while the -t- suffix is reserved for the 'addressee's sphere' and the $-n$ - suffix for 'distal' entities. But when the entities are situated in a different space and time sphere while retaining relevance for the discourse situation, the $-t$ - suffix is used for the 'past', while the $n$ - suffix is used for entities in all 'non past' situations.

\subsection{Romani}

Romani is an Indo-Aryan language spoken throughout Europe, in North and South America and in Australia. The migrants, who belonged most probably to service-providing castes (Matras 2002), arrived from India during the Byzantine Empire, around the $10^{\text {th }}$ century. Romani was considerably influenced by Greek during this period. At the end of the Byzantine era some groups migrated towards western and northern Europe and new contact languages were added.

The first dialectological classifications were carried out by Miklosich (1872-1880), reconstructing migration routes through the analysis of loan words. The Balkans Roma were 
divided into two major groups, on the grounds of religion and mobility (see Paspati 1870). On this basis, Gilliat-Smith (1915) distinguishes in Bulgaria between the nomadic Christian populations originating from Wallachia, named vlax, and the Muslim, settled groups, named non-vlax. This had considerable impact on Romani studies but more recently, a dialectal categorization based on linguistic features has become dominant, distinguishing for the Balkan area a Balkan Romani branch and a Vlach Romani branch, with the latter being geographically centered in today's Romania and including the migrants in various Europeans countries (Bakker \& Matras 1997; Elšík 2000; Boretzky \& Igla 2004).

The dialects currently spoken in Greece belong to the Balkan and Vlach Romani branches. The presence of Balkan Romani speakers is documented as early as the $11^{\text {th }}$ century and has been continuous since then. Vlach groups arrived more recently, usually in the 1920s following the Lausanne Treaty. The data presented in this paper was collected during three fieldwork trips carried out between 2005 and 2007 in a small Muslim community, of approximately 300 people, settled in the suburbs of the city of Komotini. Komotini, Gümülcine in Turkish, is particularly well-known in Romani studies because of the fact that the earliest Romani text in the Balkans was taken down there, in 1668 by Evliya Çelebi, and published in Seyahat name 'Book of travels' (see Dankoff \& Friedman 1991 for an analysis of the text).

Present-day Komotini Romani (KR) is clearly a Vlach variety that cannot be considered a direct descendant of the $17^{\text {th }}$ century Gümülcine Roma. As is often the case for the Roma communities, Komotini Roma have mixed origins; the elder ones seem to be related to various places in current Greece and Bulgaria. At present, the group is closely connected to and intermarries with other Roma groups living in various urban neighborhoods of the city or in the nearby city of Xanthi. The most common language name is romani (adj.), romane (adv.), characterized by the loss of the final $-s$. Men, women and children are trilingual in Romani, Turkish and Greek. Speakers distinguish between "pure Romani" as opposed to their own xoraxane romane, Turkish-Romani dialect. In this neighborhood, Romani is still transmitted to children, but a shift to Turkish is reported to take place in other wealthier Muslim communities. 
Figure 1. The Pomak (1) and Komotini Romani (2) vernaculars in Greek Thrace

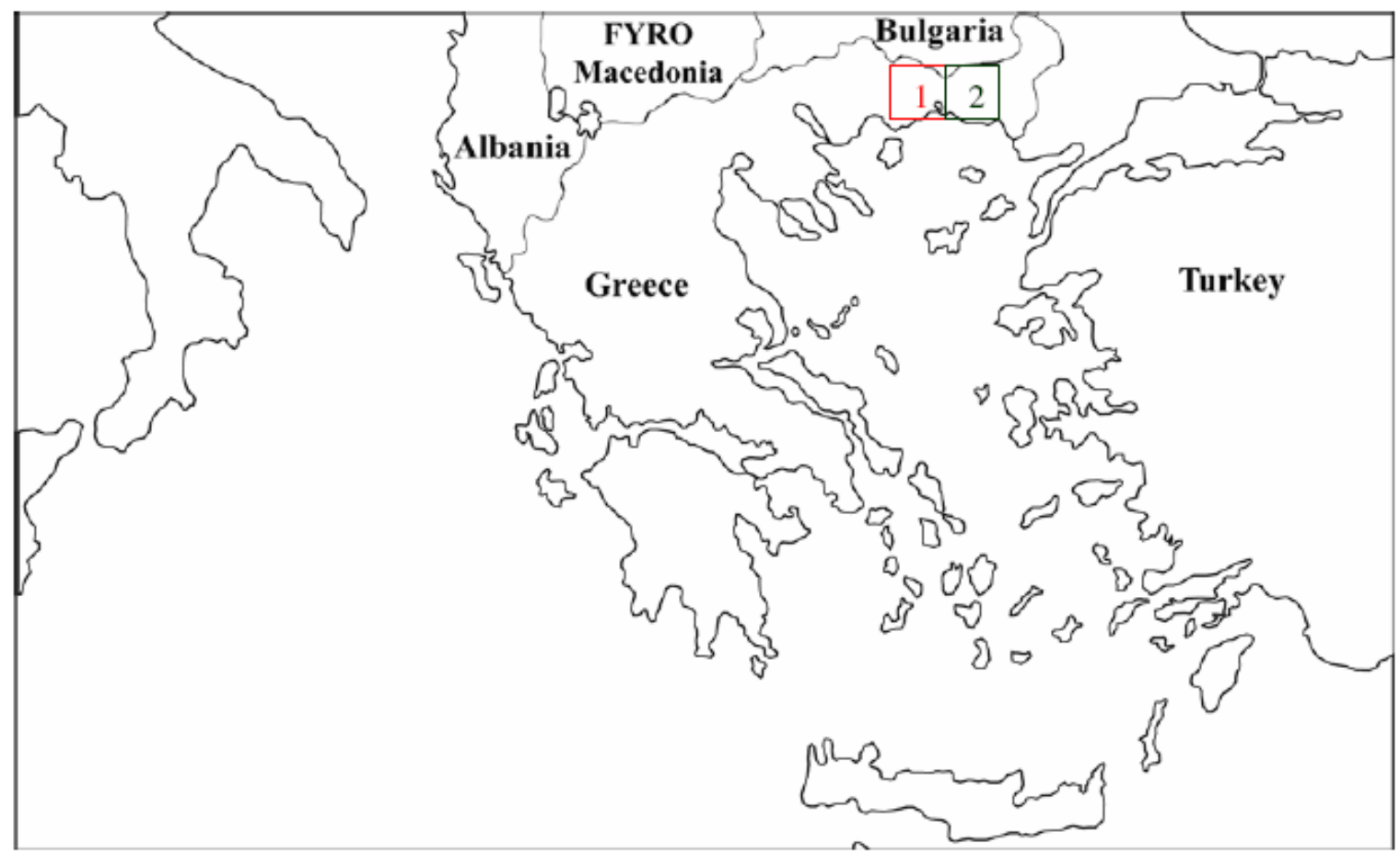

\section{LANGUAGE CONTACT OUTCOMES}

Through analysis of the contact mechanisms and processes, I now show how the results of contact with Turkish differ between Pomak1 and Komotini Romani (KR).

\subsection{Codeswitching and fused lects}

Pomak1 and Komotini Romani are significantly different at the level of bilingual speech. Pomak1 shows classic participant related codeswitching with Turkish and more importantly with Greek. As Auer describes it,

In CS (code-switching), the contrast between one code and the other (for instance, one language and another) is meaningful, and can be interpreted by participants, as indexing (contextualizing) either some aspects of the situation (discourse-related switching), or some feature of the code-switching speaker (participant-related switching) (Auer 1998: 2).

On the contrary, Komotini Romani is better understood in terms of a fused lect, a category proposed by Auer in order to describe "stabilized mixed varieties" (1998: 1): 
While LM (Language Mixing) by definition allows variation (languages may be juxtaposed, but they need not be), the use of one 'language' or the other for certain constituents is obligatory in FLs; it is part of their grammar, and speakers have no choice. (Auer 1998: 15).

Consider the following example from KR (Turkish in bold):

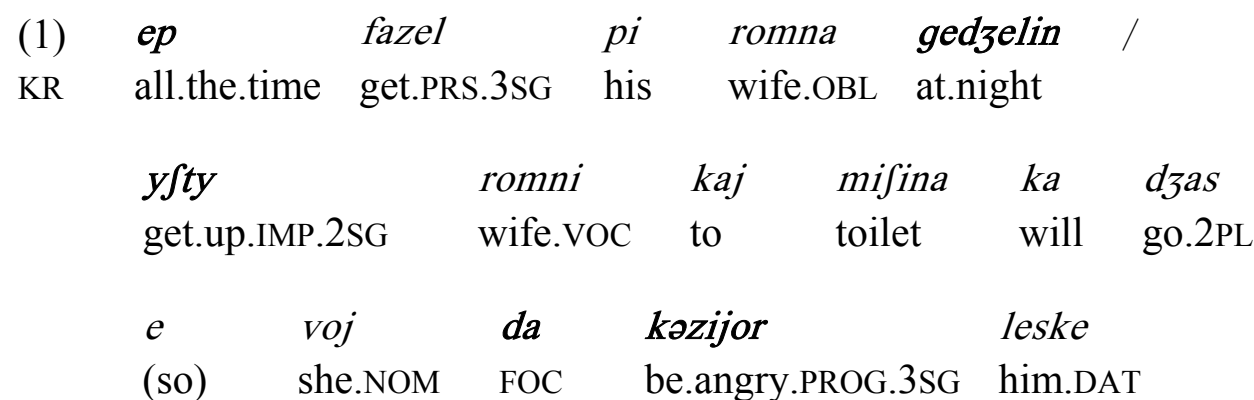

'All the time, he asked his wife, at night: 'Get up woman, we'll go to the toilet'. And so, she got angry at him...'

Excerpt from the tale "The Coward and the Giants" (Sentences 4, 5) Sound, annotation and translation of the complete texts are available online: http://lacito.vjf.cnrs.fr/archivage/languages/Romani_fr.htm

Since the KR speakers are trilingual, Greek insertions are also frequent (Greek underlined, Turkish in bold, Romanian in bold and underlined):

$\begin{array}{llllll}\text { (2) } & \text { psixoloyos } & \text { psixoloyos } & \text { jazmijor } & \text { tuke } & \text { apora } \\ \text { KR } & \text { psychologist } & \text { psychologist } & \text { write.NEG.PROG.3SG } & \text { you.DAT } & \text { pills-PL }\end{array}$

$\begin{array}{llll}\begin{array}{l}\text { kantfik } \\ \text { nothing }\end{array} & \text { NEG gives you.ACC } \\ \text { vo } \underline{\text { mono }} & \text { befel konufur tusa } \\ \text { he just } & \text { sit.PRS.3SG speak.PRS.3SG you.INSTR }\end{array}$

$\begin{array}{lllll}{[\mathrm{va}]} & \underline{\text { ute }} & \underline{\text { eksetasis }} & \text { kerel } & \text { tut } \\ \text { yes } & \text { nor } & \text { exams } & \text { make.PRS.3SG } & \text { you.ACC }\end{array}$

'A psychologist, a psychologist, doesn't prescribe pills to you. He gives you nothing. He just sits, talks to you [yes]. He doesn't make (clinical) exams either.'

Despite their superficial similarity, Greek and Turkish insertions have a very different status in KR. The Greek insertions are an aspect of discourse-related codeswitching that is not obligatory and results from relatively recent bilingualism (3-4 generations). In this example, 
Bilingual Speech and Language Ecology in Greek Thrace:

Romani and Pomak in Contact with Turkish

ute 'nor' is linked to eksetasis 'exams', which like 'psychologist' is related to Greek institutional realities. In other moments in discourse the same speaker, instead of ute 'nor' will use the Indic equivalent ne. Turkish items, on the contrary, are obligatory in the Komotini Romani dialect. Nevertheless, due to their complex networks (see Figure 2) and mobility (it is common to spend years in other Greek cities), the Komotini Roma can communicate in other Romani dialects presenting a minimum of Turkish borrowings, as is the case of Christian Roma dialects. A clear, conscious distinction is made between their own Turkish-Romani dialect and the other Romani dialects they master. This competence most likely explains some cases of variation between a Turkish loan verb and an Indic verb as can be observed in the narration of a tale (by the same speaker):

(3) KR a. oldu sap 'it became a snake' (Sentences 5, 6, 27, 38)

b. kerdindol sap 'he became a snake' (Sentences 13, 17, 24)

Excerpt from the tale "The Man-snake" http://lacito.vjf.cnrs.fr/archivage/languages/Romani_fr.htm 
Figure 2. The Komotini Roma social network (in bold the interaction language)

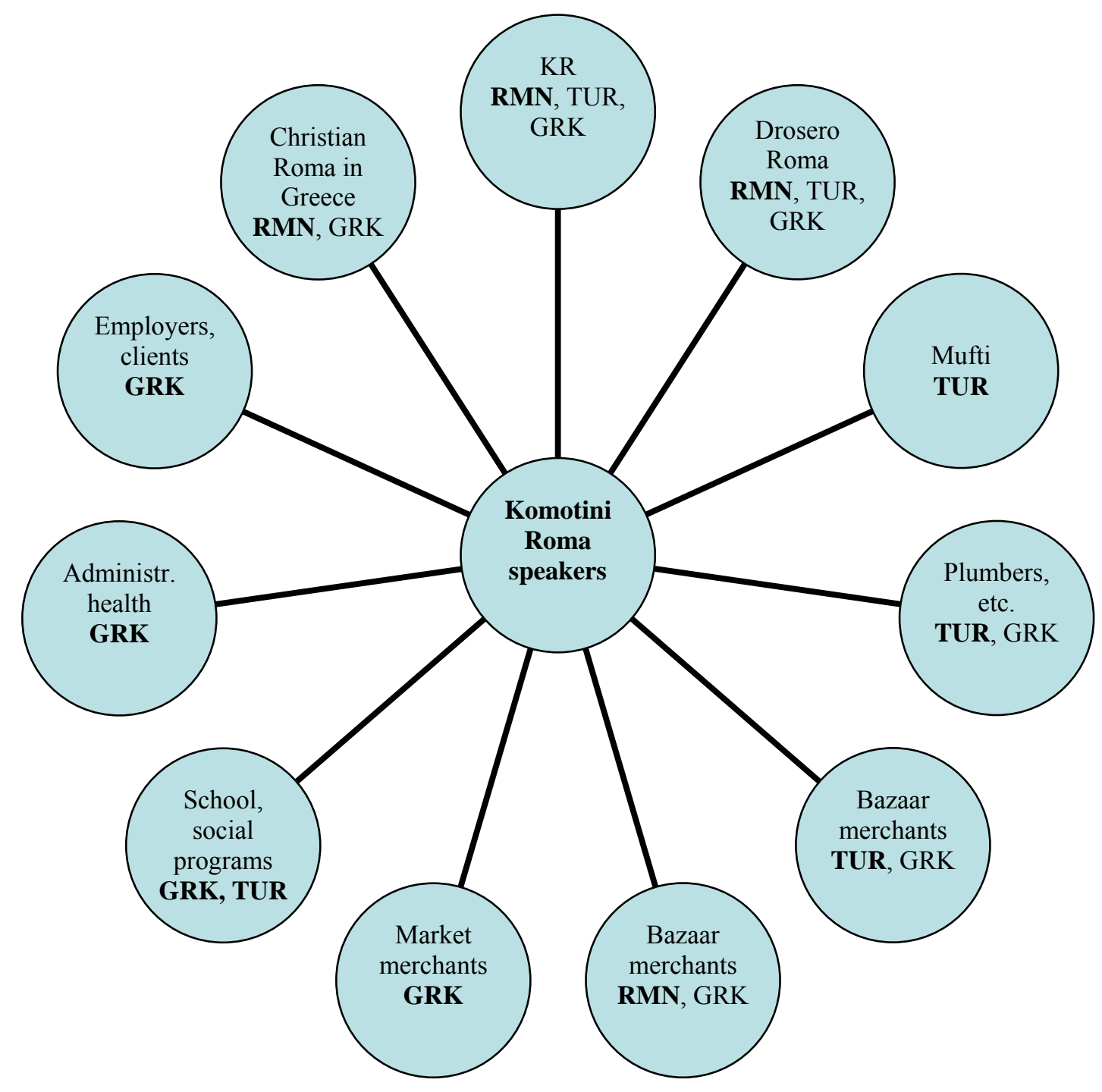

The Turkish items found in KR are not due to the current contact situation but result from the long term generalized bilingualism current during the Ottoman Empire. This is better understood when looking at the larger picture in the Balkans, where similar Turkish-Romani dialects are to be found in many Balkan countries, with more or less intense contemporary contact with Turkish (e.g. Bulgaria, Former Yugoslavic Republic of Macedonia, and Kosovo). Interestingly, comparison with the Romani dialect spoken by Christian Roma settled in the Ajia Varvara neighborhood in Athens shows that the Turkish loan verbs are used with the Turkish verb morphology even though the speakers stopped being proficient in Turkish at least 3 or 4 generations ago (see Igla 1996): 
Bilingual Speech and Language Ecology in Greek Thrace:

Romani and Pomak in Contact with Turkish

Table 1. Ajia Varvara Romani (Igla 1996: 61)

\begin{tabular}{lll}
\hline $\mathrm{V}+$ present + person $\mathrm{V}+$ present + person $\mathrm{V}+$ present + person \\
Romani verbs & Turkish verbs & $\begin{array}{l}\text { Romani loan verbs } \\
\text { from Turkish }\end{array}$ \\
\hline astar-av & bekle-r-im & bekle-r-im \\
astar-es & bekle-r-sin & bekle-r-sin \\
astar-el & bekle-r & bekle-r \\
astar-as & bekle-r-iz & bekle-r-is \\
astar-en & bekle-r-siniz & bekle-r-sinis \\
astar-en & bekle-r-lar & bekle-r-lar \\
\hline
\end{tabular}

As Auer notes, contrary to code-mixing, which requires competent bilingual speakers, "speakers of a fused lect AB may but need not be proficient speakers of A and/or B" (Auer 1998: 13). Although there is no doubt that current bilingualism helps maintain and develop this strategy in Komotini Romani, it is more than likely that grammaticalization of the Turkish insertions was completed at an earlier stage. Therefore, we need to take into consideration the contact ecology at the moment when this language mixing emerged and observe the contemporary contact ecology favoring its use and development.

\subsection{Borrowings and borrowing integration strategies}

Both Pomak1 and Komotini Romani show 'borrowing' as the main process induced by contact with Turkish. We retain 'borrowing' here in order to describe cases of transfer of forms or forms and meanings in the recipient language (Heine \& Kuteva 2005). Borrowings, contrary to codeswitching insertions, are those items that can be found in monolingual contexts or, when applicable, can be used by monolingual speakers (Matras 2009). They have their origins in the speech of bilinguals and contrary to codeswitching they require a longterm or permanent license to lift selection constraints on the use of a word-form or structure (see the continuum codeswitching - borrowing in Matras 2009).

Part of the borrowings from Turkish -many of which are of Persian origin- are common in both Pomak and Romani (despite different phonetic articulations). From a typological perspective, they also join borrowings commonly found crosslinguistically and presented in the borrowability hierarchy, an hierarchy based on "the likelihood of a category to be affected by contact-induced change" (Matras 2007: 31). 
Table 2. Shared Pomak1 and Komotini Romani borrowings from Turkish

\begin{tabular}{lll}
\hline & \multicolumn{1}{c}{ POMAK } & \multicolumn{1}{c}{ ROMANI } \\
\hline $\begin{array}{l}\text { adversative } \\
\text { 'but' }\end{array}$ & $\begin{array}{l}(\text { ama }) \\
\text { replaced by ala }(\mathrm{Gr} .)\end{array}$ & \\
\hline $\begin{array}{l}\text { negative answer particle } \\
\text { 'no' }\end{array}$ & hayir & ayir \\
\hline numerals & over 5 & (variation) \\
\hline time expressions & (variation) & \\
'in the morning' & sabalahin & sabal(a)in \\
'at x o'clock' & oniki-de & iki-sinda \\
\hline indefinites & hiç & iç \\
'at all', 'every', & her & er \\
'always' & hep & ep \\
\hline
\end{tabular}

Matras (1998) has pointed out the high borrowability of the connectors and suggested that the adversative was the most frequently borrowed (followed by 'or' > 'and'). It is interesting to note that the Greek adversative ala is slowly replacing the Turkish adversative ama in Romani and has already replaced it in Pomak1. Contrary to the crosslinguistic tendency to borrow the positive answer particle (Matras 2007), in this case both languages have borrowed the negative answer particle. Numerals are generally borrowed from the dominant language, in this case from the local trade language (of the traditional 'bazaar' market). In Romani, Turkish numerals are used for counting money while lower Romani numerals are used for entities such as days and months (note that some Romani numerals are old borrowings from Greek). In Pomak, Turkish numbers are used over five, and under five for specific cases such as telephone numbers.

Despite these shared borrowings, Pomak has fewer borrowings than Romani, but most importantly, contrary to Romani, loan verbs are very rare. In Pomak, borrowings are mainly lexical, some of them being cultural borrowings (greetings and expressing thanks), emblematic of Turkish-Muslim identity together with Turkish first and last names. Romani, on the other hand, has borrowed the Turkish $d a$, very frequently used as a focus and topic marker postposed to the noun as well as a coordinator, and the obligation marker lazım.

Still, the most significant difference between KR and Pomak1 concerns the strategies used for the integration of the borrowings in the two languages. 
Bilingual Speech and Language Ecology in Greek Thrace:

Romani and Pomak in Contact with Turkish

\section{1) Lexical integration}

In Pomak all lexical borrowings bear Slavic inflexions (for the 3 definites, case and number):

\begin{tabular}{|c|c|c|c|c|c|c|}
\hline (4) & nemame & tumafil & $n i$ & hodeme & $n a h$ & denizen \\
\hline PMK since & not.have-1PL & car & NEG & go-1PL & to & sea-DEF.DIST \\
\hline
\end{tabular}

In KR, Turkish borrowings also generally bear Indic morphology markers:

o gadzo tumafileske pare pakav kaj ni del

KR the non.Gypsy car-DAT money believe-1SG that NEG give.PRS.3SG 'The non-Gypsy, I believe that he doesn't give the money for the car.'

However, borrowed masculine nouns generally use borrowed inflexion. Such is the case for the Turkish borrowings ap-ora 'pills' (in ex. 2), dev-ora 'giants', eteklik-ora 'long skirts', etc. which take an older language contact plural, the Romanian -uri. This phenomenon is found in many Romani dialects. The names bearing foreign morphology (often of Greek origin) are called xenoclitic and are distinguished from the oikocletic names taking native morphology (for a detailed description of this complex system see Matras 2002; Elšík \& Matras 2006).

\section{2) Verb integration}

Wichmann and Wohlgemuth (2008) describe four strategies of loan verb integration that can be found crosslinguistically:

a) "light verb strategy" for cases where a verb (usually 'to do') is required to accommodate the loan verb;

b) "indirect insertion" for cases where an affix is used to accommodate the loan verb;

c) "direct insertion" for "a process whereby the loan verb is plugged directly into the grammar of the target language with no morphological or syntactic accommodation" (Wichmann \& Wohlgemuth 2008: 99).

d) "paradigm transfer" for cases where the loan verb is accompanied by the verb morphology and its meanings. This strategy is named code compartmentalisation by Friedman (In press). Komotini Romani is one of a handful of languages that are known to borrow the verb together with the time, aspect and person markers. This is characteristic of many Romani dialects: Vlach and Balkan Romani in contact with Turkish (e.g. Muzikanta, Nange, Varna Klajdži, for a complete list see Friedman in press) but also Crimean Romani, as well as Russian and 
Lithuanian Romani (see Elšik \& Matras 2006: 135). Yet, the degree to which verb paradigm transfer occurs is quite variable across these dialects.

In KR however this process is considerably developed and involves a high number and a wide range of verbs, including 'to talk', 'to tell', 'to understand', 'to think', 'to approach', 'to return', 'to wait', 'to start', 'to finish', 'to rest', 'to lie down', 'to get up', 'to touch', 'to read', 'to write', 'to count', 'to send', 'to shoot', 'to get dirty', 'to clean', 'to throw', 'to get undressed', 'to roast', 'to boil', 'to get married', 'to like'.

Almost all Turkish time, mode and aspect markers, as well as person and number markers accompany the Turkish verbs in KR. E.g. the progressive, as can be seen in the following example:

$$
\begin{array}{lllll}
\text { (6) } & \text { e } & \text { patifaja } & \text { ep } & \text { emred-ijor-lar } \\
\text { KR } & \text { the } & \text { kings } & \text { all.the.time } & \text { give.orders-PROG-3PL }
\end{array}
$$

'The kings (sultans), they are giving orders all the time.'

From Turkish emret-iyor-lar

Excerpt from the tale "The Louse and the Rom" (Sentence 3) http://lacito.vjf.cnrs.fr/archivage/languages/Romani_fr.htm

Also the r-present (in ex. 2 konu $\mathcal{\text { ur }}$ 'speak'), the Turkish preterit -di (sevindi 'he was happy'), imperative forms, the Turkish negator - $m a$ - and the Turkish future marker that can be seen in the example below:

(7) kon ama alna-ma-dzak leski kor ka tfindol

KR who.NOM but understand-NEG-FUT.3SG his throat will cut.3sG

'But the one who will not understand, I will cut off his neck.'

Excerpt from the tale "The Louse and the Rom" (Sentence 17) http://lacito.vjf.cnrs.fr/archivage/languages/Romani_fr.htm Variation exists for the expression of the optative: the Romani complementizer te occurs in some cases for Turkish loan verbs (with the present in te bekler 'to wait'; te konufur 'to talk'; with the progressive in te japiftijorlar 'to stick'), while, for other verbs, the Turkish optative marker - $(y) A$ - is to be found (uzanayim 'to lie down').

Another loan verb integration phenomenon is very common in Romani dialects all over Europe and is known as the "loan verb markers" strategy (see Elšík \& Matras 2006: 324-333; "borrowing of borrowing patterns" in Wichmann \& Wohlgemuth 2008). Loan verb markers 
Bilingual Speech and Language Ecology in Greek Thrace:

Romani and Pomak in Contact with Turkish

in Romani are often Greek-derived aspectual markers, maintained even when contact with Greek has ceased. Loan verb markers are also created from other contact languages, among which Turkish (ex. -din in the Sepečides Romani dialect, Cech \& Heinschnink 1996). Still, loan verb markers are not to be found for Turkish verbs in KR. KR speakers index such forms in the Christian Roma dialects, as shown in the following example for the loan verb marker isar:

(8) a. KR: bekle man 'Wait for me!'

b. Drama Christian Roma: bekl-isar man 'Wait for me!'

Even though this terminology is mostly applied to Romani, I believe that loan verb markers are currently found in Pomak. As shown in the following example, Pomak1 integrates Turkish verbs and adapts them to the Slavic verb morphology, but the Turkish preterit marker $-d i$ is integrated in Pomak as part of the verb radical and loses its meaning ${ }^{\mathrm{v}}$ :

(9) Se gu ytyledisam

PMK FUT 3SG iron-1SG

'I will iron it.'

From Turkish: ütüle-di V-Simple Preterit

This Turkish loanverb marker is also found in other Turkish verbs such as uidisvam 'I am matching (the colors), I am spoiling someone', sihtirdisvam 'I am fucking (used as an insult)'.

\subsection{The Komotini Romani fused lect in the mixed languages debate}

Literature on mixed languages has developed considerably over the last decades and has given rise to interesting debate on the criteria that should define a mixed language, the mechanisms that lead to their creation and the different types of mixed languages. A satisfactory definition of mixed languages has yet to be established, due to the variety of situations and probably also to the need for more detailed case studies. The number of borrowings and the type of lexicon (core or peripheral) are important elements for the distinction between languages which are mixed and those which have "heavily borrowed." According to Bakker and Mous (1994: 5), in cases of heavy borrowing, 45\% of the lexicon is borrowed, while in mixed languages the proportion may rise to $90 \%$. Intermediate categories, 
according to the authors, are not frequent. More importantly, the type of mixture is significant in that the elements of the two languages generally remain recognizable (Bakker 1994).

According to Auer (1998), mixed languages are extreme cases of fused lects. I suggest here drawing a line between fused lects, applying to cases of languages on their way to becoming mixed, and mixed languages, for cases where the process is already complete. Indeed, although KR shares some features with mixed languages it does not belong to that group (borrowed items are not as high as $90 \%$ ). But KR uses a high number of Turkish verbs, together with their time and aspect markers, and the main process is compartmentalization. As a fused lect, KR could actually provide evidence to support the role of codeswitching in the creation of mixed languages as argued by Thomason (1995) and Auer (1998) - cf. Figure 3. Although the process of language mixing is not completed, the systematic paradigm transfer of loan verbs looks like the grammaticalization of codeswitching insertions for which the speakers would have "licensed" permanent use, in Matras' terms. Current Greek codeswitching insertions, with nouns being integrated along with their native Greek inflexions, could constitute the first step in this process since they are so similar to the Turkish insertions. Only a detailed linguistic and historical analysis makes it possible to differentiate between the Greek and the Turkish insertions, in showing that the former have acquired 'permanent' and stabilized status under specific social circumstances and bilingual practices. 
Bilingual Speech and Language Ecology in Greek Thrace:

Romani and Pomak in Contact with Turkish

Figure 3. Auer's bilingual speech typology (1998: 23)

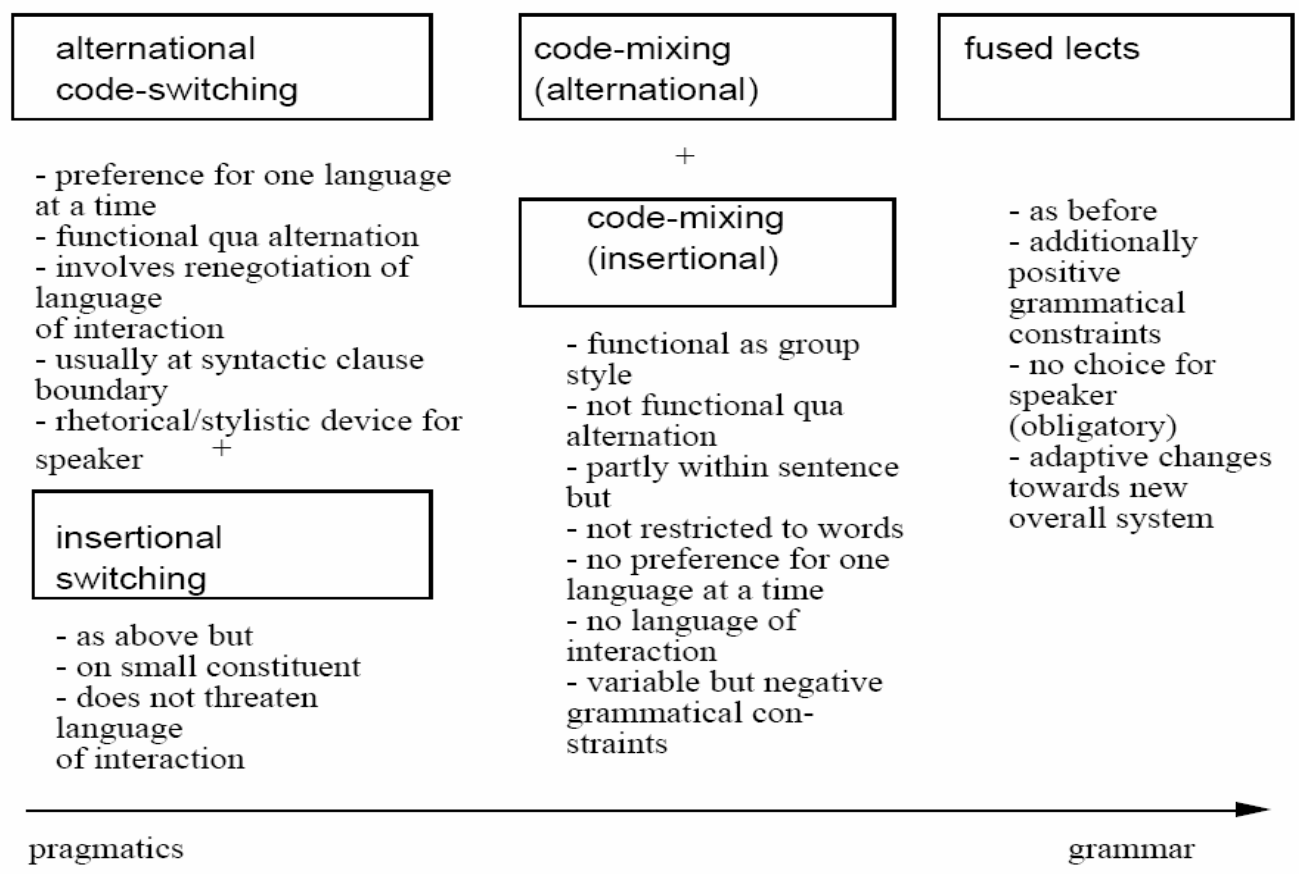

A correlation between mixed languages and language contact ecology has been suggested both by Bakker (1994) and Thomason (1995). Bakker (1994: 24) for example has suggested two types of "intertwined" languages defined by sociohistorical criteria:

1. Languages created by former nomadic groups during shift who use it as a secret language for business, e.g. Anglo-Romani;

2. Languages in mixed households e.g. Michif.

Compared to mixed languages, KR fused lect shares common features with those of the first category, as they were produced in an itinerant group. However, unlike those languages, KR was not used as a secret language and more importantly it was not created during a shift, thus pointing at those factors as relevant for the creation of mixed languages.

Thomason (1995) also relates sociohistorical characteristics of speech communities with linguistic processes of language mixing:

1. The mixed languages created in existent groups show replacement of grammar as a linguistic process (cf. Ma’a/Mbugu, Anglo-Romani).

2. The mixed languages that arise in newly rapidly formed groups show compartmentalization of the two languages' elements (cf. Media Lengua, Michif). 
Although KR was created in an already existent group, as a language related to the group's identity, it does not correlate with the process of grammatical replacement. On the contrary, the process applied is compartmentalization as found in newly formed groups. In other words, KR and Michif share the compartmentalization process (although as already mentioned above it is not as advanced in KR as in Michif) but not the social characteristics (mixed marriages, newly formed group).

Compared to other mixed Romani dialects, KR and the other Turkish-Romani dialects differ in the mechanisms they use. As shown in section 3, KR proceeds by compartmentalization while most mixed Romani dialects proceed using a combination of grammar from language A and lexicon from language B (see Boretzky \& Igla 1994 for a review of mixed Romani dialects). Follows such an example of a mixed Greek-Romani variety (Indic in bold), where the lexicon is Romani and the morphology mainly Greek:

(10) o daj-s mu avel-jazi sar-e ta lov-e

'My father brings all the money.' (Sechidou 2005: 53)

Moreover, unlike most mixed Romani languages, for which language shift has been the main mechanism, $\mathrm{KR}$ is a stabilized fused lect, used in everyday domestic and group communication in all domains and is transmitted as such to children.

\section{ECOLOGY AS A COMPREHENSIVE BILINGUAL SPEECH FRAMEWORK}

In the earliest contact setting, within the Ottoman Empire and for almost five centuries, Turkish was the lingua franca, the language of communication and trade in the Balkans. In a second contact setting, within the Greek State, which for Thrace started in 1923 and continues today, Turkish became a minority language. In Thrace, Turkish continues to be used in colloquial and trade-related contexts and has also become the language of education for the local Muslim population (1923), alongside Greek.

For both the Pomaks and the Roma, Turkish was the dominant and the prestige language, and many communities shifted to Turkish during the second half of the $20^{\text {th }}$ century. However, as shown in $\S 3$, the contact outcomes were different for the two languages under study. A closer look at the patterns of bilingualism and the patterns of language use in a historical perspective shows that contact with Turkish was materialized in considerably 
different ways for the Pomaks and the Roma. Even though the two communities show some similarities in their social characteristics (both are small, tightly-knit communities, with little intermarriage with outsiders), one can isolate the divergent factors in the Roma and Pomak ecologies that can help us understand the differences observed in the linguistic outcomes. These factors include the geographical setting of their traditional habitats (mountains vs. urban habitat) and the impact on the communities' social structure (isolated, with little outside contact vs. daily contact despite marginalization), the socio-professional occupations (cattle breeders and farmers vs. craftsmen and merchants) and their mobility (itinerant vs. semisedentary) and what those factors imply for language contact patterns (extensive vs. limited bilingualism; intensive vs. occasional use). I will also pay close attention to the role of religion and other cultural practices for the impact they have on language contact (institutional language contact through religion and education) related to the identity issues and linguistic representations (prestige) that affect the intensity of bilingualism and that in many cases lead to shift.

\subsection{Roma language contact ecology and patterns of bilingualism}

Thomason (2001) observes that, contrary to pidgins and creoles, bilingual mixed languages are developed in widespread bilingual settings. On a more specific point, Wichmann and Wohlgemuth propose a correlation between loan verb integration strategies and the "degrees to which speakers of the target language are exposed to the source language(s)" (2008: 12). The paradigm transfer of loan verbs, found in $\mathrm{KR}$, is at the top of the hierarchy, related to the most intensive contact. Indeed, Komotini Roma most probably presented extensive and intensive long-term bilingualism with Turkish, the vehicular language of the Ottoman Empire. Extensive in that bilingualism with Turkish concerned a large part of the speech community, women and children included. Intensive, in that Turkish was used frequently in everyday interaction and in highly argumentative contexts.

The Komotini Roma's socio-professional activities and mobility also furnish elements for understanding this sort of language contact. Demographic information concerning the Ottoman period is scarce, especially for populations such as the Roma, traditionally living at the margins of the administration. But linguistic and ethnographic evidence seem to indicate that the Komotini Roma were most likely itinerant craftsmen during Ottoman times. The elders report traditional occupations just as commonly found for the Southern Vlach Roma in general: according to them, their ancestors used to work as džambazi, horse and donkey traders (a professional activity also found in the Gurbet dialect in the Former Yugoslav Republic of Macedonia); tarahtči, comb makers (wood combs for animals and cow bone 
combs for people); while others would make sieves, porizena, made of lamb skin. Women would also practice fortune telling. Those professional activities implied frequent contact with outsiders and required an argumentative discourse in order to convince and negociate with the clients.

Matras's (2005) dialectological analysis establishes two large geographical zones, separated by the "Great Divide" isogloss, which correspond roughly to the Ottoman and the Austrian zones of influence. Accordingly, one can conclude that the itinerant Roma's mobility was limited to the Balkans, within the Ottoman zone where Turkish was the trade language. The change in the political boundaries that resulted from the formation of the Modern Greek State had an impact on the Komotini Roma's mobility (as was the case for other nomads, e.g. for the Greek speaking Sarakatsani shepherds). The Komotini Roma became semi-sedentary and adjusted their working activities to the new borders. Modern Greek was added to their linguistic competencies while Turkish remained their trade language in Thrace. Today, Roma of the Komotini neighborhood work as seasonal workers in agriculture, trade (although the richest and most powerful market merchants are the Christian Roma settled in Kimeria, near Xanthi), or work occasionally as cleaning staff for domestic or city services. Even though Komotini Roma are currently settled, they remain semi-sedentary, in most cases for professional reasons.

Traditionally, the whole Roma family participates in the nomadic lifestyle. Intensive codeswitching probably took place at that period and then, at some point, as Thomason (2001) suggests, the codeswitching became fossilized by acquiring the function of indexing the specific group. "Commercial nomadic" groups are also known for developing specific ingroup languages (see Glemch \& Glemch 1987). Indeed, the Komotini Roma rely on their Turkish identity both for group and individual naming. Muslim Roma have Turkish first and last names and they refer to their group as xoraxane roma 'Muslim, Turkish Roma'. Xoraxane indicates their Muslim religion, indexing them in the larger group of Muslim Roma in the Balkans, and distinguishing them from the dasikane roma 'Christian Roma, Greek Roma'. vi The xoraxane women usually wear the 'sarouel', sosten, distinguishing themselves from the Christian Roma who wear long, wide skirts eteklikora (the younger ones can also be dressed in a "western manner"). ${ }^{\text {vii }}$

The "license" to mix the two languages goes back to a long tradition of multilingualism that can be considered part of the Roma identity. Traces of the various contacts in the Roma history are still to be found in the modern dialects (for example from old contact languages such as Greek, Romanian, Slavic, etc.). 
Bilingual Speech and Language Ecology in Greek Thrace:

Romani and Pomak in Contact with Turkish

The processes used for this mixing seem quite conscious, in accordance with recent approaches of the bilingual speaker as an active "language builder" (Hagège 1993). Borrowings are marked through specific strategies which allow them to be integrated and yet to remain distinctive and identifiable centuries after the contact has ceased. In the case of KR those strategies are the use of xenoclitic nouns and of paradigm transfer in verb borrowing. This linguistic compartmentalization strategy also reflects Roma social organization and their rules towards outsiders. While Roma were in constant contact with outsiders and their economy relied on trade and services with the gadze, i.e. the non-Roma, at the same time, many Roma communities had strict rules of avoidance of outsiders. The most notorious expression of it is the marime, a term used by the Vlach Roma. Marime refers to a complex set of norms, varying from one group to another, defining "uncleanness" and to the expulsion imposed in case of violation of those rules or for behavior disruptive to the community (Weyrauch 2001). According to Miller:

'Marime developed as an ecological response to nomadic and segregated living in arrangements in wagons and tents when certain rules concerning health, sexual expression and social intercourse with outsiders proved adaptive.' (Miller 1975)

Marime regulated contact among the Roma as well as contact with the non-Roma, the gadze. Defilement with the non-Roma can be seen in the traditional distance with religious, educational or health institutions. Even today, $60 \%$ of Roma children in this small neighborhood of Komotini never attend primary school, a very low percentage compared to the Christian Greek Roma in other parts of Greece. This stems both from the inadequate policies of the local Greek administration, and from the traditional distance to school, due to assimilation policies threatening the Roma culture. Contact with Muslim institutions is similar: mosques are not to be found even in neighborhoods of 4000 inhabitants such as Drosero in Xanthi. Muslim holidays, e.g. Seker bairam or kurban bairam, are seldom celebrated and the Roma I interviewed think of them as quite recent (later than the 1960s).

Even though such marginalization is characteristic of the Roma in Europe and throughout their history, cases of relative insertion in modern States are not uncommon: for example, the sedentary Sepečides Roma in Turkey show "an increasing number of exogamic marriages" (Cech \& Heinschnink 1996: 2). Children attend Turkish schools and the group is shifting to Turkish. Another example of integration is the case of the Ajia Varvara Roma, a 
mixed Greek and Roma neighborhood in Athens, where children also attend primary school (Kozaitis 2002).

\subsection{Pomak language contact ecology and patterns of bilingualism}

During the Ottoman period the Pomak speech community was composed of a majority of monolingual speakers with practically no direct contact with Turkish. Turkish was introduced through Koranic School and through the members of the community who traveled. During the modern contact setting within the Greek State, contact with Turkish was intensified through primary school, mass media and increasing contact situations (travel, migration and urbanization). This type of low-level contact, which gave place to few lexical borrowings, can be understood through the speech community's social and geographical environment.

Pomaks were traditionally semi-sedentary cattle-breeders and farmers, living in the Rhodope Mountains. Some of those areas remain hard to access even today, especially in winter. Pomaks would practice seasonal grazing, spending winters in their villages and migrating in the summer to nearby summer settlements, along with their families and cattle. This way of living involved little contact with outsiders and effective bilingualism with Turkish was limited to the elite and those few who for professional reasons were part of the Turkish speaking networks. This isolation continued within the Greek State, during the Cold War, due to the status of epitirumeni zoni, 'surveillance zone', implying military control of the borders with neighboring Communist countries (Bulgaria in this area). In practice this meant limited access to the closest cities. Today, the situation has considerably changed and contacts with the city of Xanthi have intensified, making it possible in many cases for men to work in the city and to continue living in the village.

Since Ottoman times, Pomaks have been in contact with Turkish mainly through religion and school. This strong Muslim culture is reflected in the type of borrowings to be found: Pomak speakers make use of a high number of religious terms for greetings and expressing thanks, which are either borrowings from Turkish or terms used broadly in the Muslim-Arabic culture and borrowed through Turkish: 
Bilingual Speech and Language Ecology in Greek Thrace:

Romani and Pomak in Contact with Turkish

Table 3. "Emblematic" borrowings from Turkish in Pomak1

\begin{tabular}{ll}
\hline greetings & salam alekum (Arabic) \\
& meraba 'hello' (Turkish> Arabic) \\
& hoSgeldin 'welcome' \\
& igjed 3eler 'good night' \\
\hline thanking expressions & allah kabulele (Arabic) \\
& bereket varsin \\
\hline close kinship terms & bubajko 'father' (reg. buba) \\
& anne 'mother' \\
& abla 'elder sister' \\
bubanne '(paternal) grandmother'
\end{tabular}

Religion was, and still is, an important aspect of Pomak identity: Pomaks in Greece distinguish themselves from the Bulgarians, the neighboring Christian Slavs, according to the Ottoman organization based on religion. Today, most Pomak villages have a mosque, Pomak imams and regional muftis educated in Arabic countries. The hadj pilgrimage to Mecca is prestigious and widely practiced; religious events are carefully observed and married women dress in the Muslim way (covering their hair with scarves, the mumie or mandil replacing the traditional white testemel brought from Mecca, and wearing long clothes to cover their bodies). Boys and girls go to the Koranic School kuran kursu, and even though Koranic Arabic is taught, Turkish is the classroom language. Turkish is also, together with Greek, the language of minority primary school education even though the number of students attending monolingual Greek schools has considerably increased in the last decade due to permanent migration to Xanthi and research for the best school education. It is important to keep in mind that until very recently, education concerned only a small part of the community and that up until the early 1990s girls would not pursue their studies beyond primary school.

Another source of contact with Turkish is recent migration for work and education in Turkey and Germany. In the 1980s the migrants would settle in Germany with their families, they would become integrated in the immigrant Turkish communities and would frequently shift to Turkish. Contact between relatives would remain intense, either by telephone or visits. In the last decade, reorganization in working migration politics has made it rare for whole families to migrate to Germany. Today, young men have working contracts limited to a few months, after which they return to their original village and take up other sorts of activities. 
Occasional visits to neighboring Turkey are common, for shopping or tourism, facilitated by the Egnatia road. Turkish television and music are also influential sources of contact: elder women who have not attended school or had any mobility outside their village, point to television as an influential source of contact with Turkish.

\subsection{Typological factors}

In parallel with the identification of social factors studies in contact linguistics have examined the typological parameters that influence contact induced phenomena. Poplack and Sankoff (1988) argue that typologically similar languages will tend to produce alternational codeswitching, while typologically distinct languages produce insertional codeswitching. Muysken (2000) shows that if an agglutinative language is the matrix language, then the resulting codeswitching will be insertional; while, if both languages are flectional, alternational codeswitching will be the result. Winford (2003) also underlines the importance of typological distance in contact settings determining the linguistic results to a great degree.

In the case presented here, however, typological factors do not seem to be relevant, since both recipient languages are flectional, and the source language is Turkish, an agglutinative language. For example, the type of time, mode and aspect markers does not determine the paradigm transfer used in Romani nor the integration strategy used in Pomak: the Romani $k a$ and Pomak $\int e$ future markers are enclitic to the verb in both cases. But, in Romani, Turkish verbs are borrowed along with the Turkish future marker, while in Pomak the verb is integrated into Pomak morphology and maintains the Pomak "will" marker. Moreover, evidence exists for the paradigm transfer of loan verbs in Romani with Russian as the donor language, i.e. a flectional language.

The paradigm transfer for loan verbs has also been considered from a typological perspective. Through a rich sample of Romani dialects, Elšik and Matras (2006: 134-136) show, for example, that third person markers are more likely to be borrowed, followed by second person and then first person markers. Person and number markers also seem to depend on aspect markers. Note that in KR all person markers are transferred with the Turkish loan verb. Based on available data from other Romani dialects in the Balkans, Friedman (In press) proposes a hierarchy of Turkish TMA markers accompanying the Turkish loan verbs in Romani (note that $\mathrm{KR}$ is very advanced along this scale):

preterit $<$ present $[-r \sim$-yor $]<$ clitic cop. $i d i<$ optative $<m I s$-past $<$ future $\&$ negation $<$ infinitive 
Bilingual Speech and Language Ecology in Greek Thrace:

Romani and Pomak in Contact with Turkish

\section{CONCLUSION}

In this paper, I have compared two sorts of close-knit speech communities, showing long term contact with Turkish. In both cases Turkish is the dominant, prestigious language and, more significantly, an important language for the group's identity. Despite these shared features, the outcomes of language contact differ: Pomak shows a low level of borrowing, though of an often emblematic, religious type, and infrequent, participant related codeswitching. Romani on the other hand shows a high number of borrowings and can be described as a fused lect in Auer's terminology.

The aim of this paper was to show that the study of the contact ecology of the two communities leads to a better understanding of these differences: it shows how for the Roma itinerant craftsmen contact with Turkish was intensive and extensive, while, on the contrary, Pomaks having long been isolated, semi-sedentary cattle-breeders, had little contact with Turkish, and mostly through institutions (religion and education), in what may be considered a normative context. Figure 4 presents an implicational scale showing how the speech community's professional profile and mobility determine the language contact settings, and how those in turn shape the resulting type of bilingualism and bilingual discourse. The factors shown in Figure 4 should not be viewed individually, but as a correlation of factors that are likely to produce a certain type of bilingual speech.

Figure 4. Pomak and Roma ecology and bilingual speech with Turkish

POMAKS

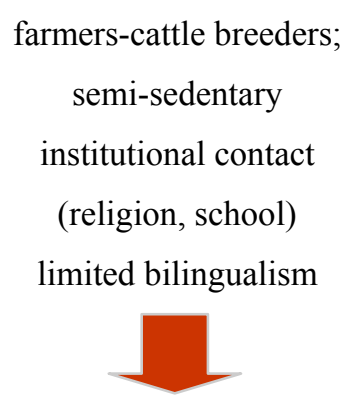

codeswitching
ROMA

craftsmen - merchants;

itinerants

colloquial contact

(no institutional contact)

intensive and extensive bilingualism

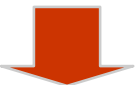

fused lect

This case study does not aim to produce a novel universal contact typology, but rather to confirm and specify the existing typologies suggested by Thomason and Kaufman (1988), Loveday (1996) and Winford (2003). More specifically, it supports the observation that some 
social correlations may favor some types of contact outcomes: institutional and infrequent bilingualism of isolated speech communities is most likely to produce some borrowings and no further significant impact on the language; a tight-knit speech community with a long bilingual tradition, for commercial purposes and involving child bilingualism, may give rise to more complex types of language mixing.

This comparison between two radically different communities attempts to provide a clear example of the role that language ecology plays in multilingual settings. What would be more challenging is the comparison between various Romani dialects, in contact with Turkish or other languages (Greek, Slavic, Romanian), in order to identify the relevant external parameters. This supposes first hand, detailed knowledge of the local conditions making such comparison extremely difficult to carry out given the complexity of each situation.

\title{
Abbreviations
}

\begin{tabular}{|c|c|}
\hline $\begin{array}{l}1,2,3 \mathrm{SG}-\text { first... } \\
\text { singular }\end{array}$ & $\begin{array}{l}\text { FYRO Macedonia - Former } \\
\text { Yugoslavic Republic of }\end{array}$ \\
\hline 1,2,3PL - first... person plural & Macedonia \\
\hline ACC - accusative & FUT - future \\
\hline DAT - dative & GEN - genitive \\
\hline DEF.DIST - distal definite & INSTR - instrumental \\
\hline & IMP - imperative \\
\hline
\end{tabular}

\author{
KR - Komotini Romani \\ $\mathrm{NOM}$ - nominative \\ NEG - negation \\ PMK - Pomak \\ PROG - progressive \\ TMA - Tense, Mood, Aspect \\ TUR - Turkish \\ VOC - vocative
}

\section{BIBLIOGRAPHY}

Adamou, Evangelia. (In press a, 2010). Le marquage différentiel de l'objet en nashta et en pomaque (slave, Grèce). Revenir sur l'hypothèse du contact de langues. Bulletin de la Société de Linguistique de Paris 105/1.

- (In press b). Deixis and temporal subordinators in Pomak (Slavic, Greece). In I. Bril (ed.), Clause-Hierarchy and Clause-Linking: The Syntax and Pragmatics Interface, Amsterdam/Philadelphia: Benjamins.

Adamou, Evangelia \& Drettas, Georges (2008). Slave. In E. Adamou (ed.), Le patrimoine plurilingue de la Grèce, 107-132. Leuven: Peeters.

Aikhenvald, Alexandra \& Dixon, R.M.W. (eds) (2007). Grammars in Contact: A crosslinguistic approach, Oxford: Oxford University Press. 
Bilingual Speech and Language Ecology in Greek Thrace:

Romani and Pomak in Contact with Turkish

Auer, Peter (1998). From Code-switching via Language Mixing to Fused Lects: Toward a Dynamic Typology of Bilingual Speech. Interaction and Linguistic Structures 6: 1-28.

Bakker, Peter (1994). Michif, the Cree-French mixed language of the Métis buffalo hunters in Canada. In Bakker P. \& Mous M. (eds), Mixed languages: 15 case studies in language intertwining, 13-33. Amsterdam: IFOTT.

Bakker, Peter \& Matras, Yaron (1997). Introduction. In Matras, Y. Bakker, P. \& Kyuchukov, H. (eds), The Typology and Dialectology of Romani, 7-30. Amsterdam: John Benjamins.

Bakker, Peter \& Mous, Maarten (1994). Introduction In Bakker P. \& Mous M. (eds), Mixed languages: 15 case studies in language intertwining, 1-11. Amsterdam: IFOTT.

Boretzky, Norbert \& Igla, Birgit (1994). Romani Mixed Dialects. In Bakker P. \& Mous M. (eds), Mixed languages: 15 case studies in language intertwining, 35-68. Amsterdam: IFOTT.

- (2004). Kommentierter Dialektatlas des Romani. Teil 1, Vergleich der Dialekte. Wiesbaden : Harrassowitz.

Cech, Petra \& Heinschnink, Moses (1996). Sepečides-Romani. Muenchen: Lincom.

Dankoff, Robert \& Friedman, Victor (1991). The Earliest Text in Balkan (Rumelian) Romani: A Passage from Evliya Çelebi's Seyahat nameh. Journal of the Gypsy Lore Society, Fifth Series 1/1: 1-20.

Elšík, Viktor (2000). Dialect variation in Romani personal pronouns. In Elšík, V. \& Matras, Y. (eds.) Grammatical relations in Romani: The noun phrase, 65-94. Amsterdam: Benjamins.

Elšík, Victor \& Matras, Yaron (2006). Markedness and Language Change. Berlin, NY: Mouton de Gruyter.

Friedman, Victor (In press). Compartmentalized Grammar: The Variable (Non)-Integration of Turkish Verbal Conjugation in Romani Dialects. In Elšík V. (ed.), Anthropological approaches to Romani Linguistics. Munich: Lincom.

Gilliat-Smith, B. J. (1915). A report on the Gypsy tribes of North East Bulgaria, Journal of the Gypsy Lore Society, New Series 9: 1-55, 65- 109.

Glemch, George \& Glemch, Sharon (1987). Commercial Nomadism: Occupation and Mobility among Travellers in England and Wales. In Aparna Rao (ed.), The Other Nomads: Peripatetic Minorities in Crosscultural Perspective, 133-153. Cologne: Böhlau. Gumperz, John J. (1982). Discourse strategies. Cambridge: Cambridge University Press. Haugen, Einar (1972). The ecology of language. Stanford: Stanford University Press. 
Hagège, Claude (1993). The language builder. Amsterdam: Benjamins.

Heine, Bernd \& Kuteva, Tania (2005). Language Contact and Grammatical Change. Cambridge: Cambridge University Press.

Igla, Birgit (1996). Das Romani von Ajia Varvara - Deskriptive und historisch vergleichende Darstellung eines Zigeunerdialekts. Wiesbaden: Harrassowitz.

Kopitar, Jernej (1829). Albanische, walachische und bulgarische Sprache. Jahrbücher der Literatur (Wien) 46: 59-106.

Kozaitis, Kathryn (2002). Embrace of shelter: The cultural hybridism of Athenian Roma. Oi Roma stin Elladha, 137-168. Athens: Elliniki Etairia Ethnolojias.

Loveday, Leo J. (1996). Language Contact in Japan: A Socio-linguistic History. Oxford: Clarendon Press.

Matras, Yaron (1998). Utterance modifiers and universals of grammatical borrowing. Linguistics 36/2: 281-331.

- (2002). Romani: A linguistic introduction. Cambridge: Cambridge University Press.

- (2005). The classification of Romani dialects: A geographic-historical perspective. In Halwachs, D. \& Schrammel, B., Ambrosch, G. (eds.), General and applied Romani linguistics, 7-26. Munich: Lincom.

- (2007). The borrowability of structural categories. In Matras, Y. \& Sakel, J. (eds). Grammatical borrowing in cross-linguistic survey, 31-73. Berlin, NY: Mouton de Gruyter.

- (2009). Language contact. Cambridge: Cambridge University Press.

Matras, Yaron \& Sakel, Jeannette (eds) (2007). Grammatical borrowing in cross-linguistic survey. Berlin, NY: Mouton de Gruyter.

Miklosič, Franz (1861). Die slavischen Elemente im Rumunischen. Denkschriften der Kaiserlichen Akademie der Wissenschaften, Philosophisch-historische Klasse 12: 1-70.

- (1872-1880). Über die Mundarten und Wanderungen der Zigeuner Europas. vol. 3. Vienna: Karl Gerold's Sohn.

Miller, Carol (1975). Machwaya Gypsy Marime. In Rehfisch (ed.), Gypsies, Tinkers and Other travelers, 41-54. London: Academic Press.

Muysken, Pieter (2000). Bilingual Speech. A typology of Code-mixing. Cambridge: Cambridge University Press.

Mufwene, Salikoko (2001). The ecology of language evolution. Cambridge: Cambridge University Press.

- (2005). Créoles, écologie sociale, évolution linguistique. Paris: L'Harmattan. 
- (2008). Colonization population contacts and the emergence of new language varieties: A response to Peter Trudgill. Language in Society 37/2: 254-259.

Myers-Scotton, Carol (1993a). Social Motivations for Codeswitching: Evidence from Africa.

Oxford: Oxford University Press.

- (1993b). Duelling languages: grammatical structures in Codeswitching. Oxford: Clarendon Press.

Paspati, Alexander (1870, reprint 1973). Etudes sur les tchinghianés de l'empire ottoman. Osnabrück: Biblio Verlag.

Poplack, Shana (1980). Sometimes I'll start a conversation in Spanish Y TERMINO EN ESPANOL: Toward a typology of code-switching. Linguistics 18: 581-616.

Poplack, Shana \& Sankoff, David (1988). Code-switching. In U. Ammon, N. Dittmar and K.J. Mattheier (eds), Sociolinguistics, vol. 2., 1174-1180. Berlin: Walter de Gruyter.

Sandfeld, Kristian (1926). Balkanfilologien. Copenhague (tr. 1930 Linguistique balkanique. Paris: Kliensieck).

Schleicher, August (1850). Die Sprachen Europas.

Sechidou, Irene (2005). Finikas Romika: A Greek Para-Romani variety. Romani Studies 5, 15/1: 51-79.

Silva-Corvalàn, Carmen (1994). Language Contact and Change: Spanish in Los Angeles.

Oxford: Clarendon.

Thomason, Sarah (1995). Language mixture: ordinary processes, extraordinary results. In C. Silva-Corvalàn (ed.), Spanish in Four Continents: Studies in Language Contact and Bilingualism, 15:33. Washington, D.C.: Georgetown University Press.

- (2001). Language Contact: An Introduction. Edinburgh: Edinburgh University Press.

Thomason, Sarah \& Kaufman, Terrence (1988). Language Contact, Creolization, and Genetic Linguistics. Berkeley/Los Angeles: University of California Press.

Troubetzkoy, Nicolay (1928). Actes du 1er Congrès International des Linguistes. La Haye. Trudgill, Peter (1989). Contact and isolation in linguistic change. In Leiv Egil Bervik \& Ernst Hakon Jahr (eds), Language Change: Contributions to the Study of its Causes, 227-237. Berlin: Mouton de Gruyter.

- (2008). Colonial dialect contact in the history of European languages: On the irrelevance of identity to new-dialect formation. Language in Society 37/2: 241-254.

Voegelin, C.F. \& Voegelin, F.M. \& Schultz, Noel W. (1967). The language situation in Arizona as part of the Soutwest culture area. In Dell Hymes and Willima E. Bittle, Studies in Southwestern ethnolinguistics, 403-451. The Hague: Mouton. 
Weyrauch, Walter O. (ed.) (2001). Gypsy Law: Romani Legal Traditions and Culture. Berkeley: University of California Press.

Weinreich, Uriel (1953). Languages in Contact. New York: Linguistic Circle of New York. Wichmann, Søren \& Wohlgemuth, Jan (2008). Loan verbs in a typological perspective. In Stolz T., D. Bakker \& R. Salas Palomo (eds.), Aspects of Language Contact. New Theoretical, Methodological and Empirical Findings with Special Focus on Romancisation Processes 89-121. Berlin/New York: Mouton de Gruyter. Winford, Donald (2003). An introduction to Contact Linguistics. Oxford: Blackwell.

ACKNOWLEDGMENTS: I gratefully acknowledge support from the Lacito-CNRS for the fieldwork trips and the Federation of Linguistic Typology and Universals-CNRS for the preparation of this paper. This paper has benefited greatly from the critical comments of the two anonymous reviewers and the editor of the Journal. Many thanks to Peter Auer, Victor Friedman and Birgit Igla for discussion on the Romani data and Elif Divicioglu for Turkish. I also sincerely thank all the speakers who participated in this study.

${ }^{\mathrm{i}}$ An earlier version of this paper, "Contact de langues et écologie : le romani et le pomaque au contact du turc (Thrace, Grèce)", was presented at the Ecology and Language Evolution Workshop, co-organized by E. Adamou, F. Jacquesson and C. Taine-Cheikh, on October 23, 2008 in Lacito-Villejuif.

ii Given political pressures bearing on Pomak speakers, within a context of linguistic shift to Turkish, I have decided not to mention the villages' names, despite the obvious interest this would present from a dialectological perspective. Pomak1 stands for the village of the Xanthi area.

iii I have also done fieldwork in traditionally Pomak speaking villages, in the Evros county and the Xanthi district, confirming the shift to Turkish for the younger generations.

${ }^{\text {iv }}$ Auer already mentioned some Romani dialects as fused lects and cited the example of Sinti Romani.

${ }^{v}$ The affix $-s a-$, following $-d i$-, could also be a loan verb marker, of Greek origin this time, frequently used as an adaptation marker in loan verbs from Greek in many Slavic languages.

vi While in most Romani speaking communities the Greeks are called balame (also in Paspati), here they are named dasikane, a name used elsewhere for Slavs.

vii But Roma women do not cover themselves in the Muslim way as e.g. Pomak women do. 